\title{
The Use of the $\lambda$ Bacteriophage to Neutralize the Pathogenic Effects of Shiga Toxins from Escherichia Coli to Combat Antimicrobial Resistance: A Research Protocol
}

Jessica M. Karlovcec, BSc Student [1]*, Brendan D. Paget, BSc Student [2], Emma L. Veres, BSc Student [1]

[1] Department of Molecular and Cellular Biology, University of Guelph, Guelph, Ontario, Canada, N1G 2W1

[2] Department of Engineering and Physical Science, University of Guelph, Guelph, Ontario, Canada, N1G 2W1

*Corresponding Author: jkarlovc@uoguelph.ca

\begin{abstract}
Introduction: Resistance to antibiotics is becoming a global health crisis. Certain strains of Escherichia coli bacteria are resistant to antibiotic drugs and thrive without competition. Pathogenic effects of E. coli are caused by Shiga toxins they produce. Instead of attempting to kill the pathogens, we propose altering the bacterial genome of $E$. coli, causing the expression of globotriaosylceramide $\left(\mathrm{Gb}_{3}\right)$ receptors, effectively neutralizing produced toxins.

Methods: Phages are introduced to cultured E. coli cells and incorporate their DNA into the bacterial genome. Mutation vectors are transformed into $E$. coli cells using electroporation, causing expression of $\mathrm{Gb}_{3}$ receptors and preventing the lysing of the cell. Next, exposure to UV light causes phages to enter the lytic cycle, and mutated phages can be collected. Then, $E$. coli cells will be administered to 28 Wistar rats, and phage treatments causing expression of $\mathrm{Gb}_{3}$ receptors on $E$. coli cells will be administered to the treatment group. Rats in both groups will be monitored for symptomatology of $E$. coli poisoning, and stool samples will be collected and analyzed for quantities of Shiga toxins.

Anticipated Results: We anticipate that phage-treated E. coli cells will express $\mathrm{Gb}_{3}$ receptors. We expect that, in the control group, symptoms of E. coli poisoning and quantities of Shiga toxins will increase over the duration of the study. Upon adequate expression of $\mathrm{Gb}_{3}$ receptors, we expect symptoms of $E$. coli poisoning and quantities of Shiga toxins to be lower in the treatment group than in the control group throughout the study.

Discussion: Confirmation of our anticipated results through immunofluorescence spectra visualizing $\mathrm{Gb}_{3}$ receptors, histogram plots of symptoms, and lateral flow assays detecting quantities of Shiga toxins will prove our methods to be a valuable asset for decreasing the effects of $E$. coli poisoning and related diseases.

Conclusion: Antibiotic resistance is becoming a serious threat. As antibiotic drugs are designed to kill bacteria, we propose an alternative method to neutralizing the pathogenic effects caused by $E$. coli through the incorporation of $\mathrm{Gb}_{3}$ receptors, and allowing the proliferation of the bacteria. This suggests an approach to slowing the acceleration of antibiotic resistance.
\end{abstract}

Keywords: Shiga toxin; Escherichia coli; $\lambda$ bacteriophage; globotriaosylceramide receptor; antibiotic resistance; recombineering

\section{Introduction}

A major challenge for modern medicine is the prevalence of antibiotic resistance to human pathogens [1]. There are currently 18 antibiotic-resistant bacteria and fungi that are classified as either urgent, serious, or concerning threats to human health, and many more are currently developing antibiotic resistance [2]. Antibiotics are used to target susceptible bacteria, however, bacteria with protective mutations and other factors have survival advantages that allow them to flourish on available nutrients, gaining a competitive fitness advantage [1]. Instead of killing the bacteria, we propose genetic modification of the bacteria infecting a given organism to impair toxin effectiveness, thereby reducing bacterial virulence.

Shiga toxin-producing Escherichia coli is estimated to cause 2,801,000 global infections annually [3]. Shiga toxins can be absorbed and neutralized by bacteria possessing an extracellular $\mathrm{Gb}_{3}$ receptor [1]. $\mathrm{Gb}_{3}$ receptors function by recognizing the $\mathrm{B}_{5}$ subunit of the Shiga toxin, triggering endocytosis. This will allow for the cell to internalize the receptor and its coupled toxin, where the cell will degrade the toxin into separate components. This $\mathrm{Gb}_{3}$ receptor can be synthesized in E. coli strains possessing a waaO 
mutation in the lipopolysaccharide (LPS) biosynthesis genome locus [1]. This mutation prevents LPS from being fully synthesized on the bacterium's outer membrane, therefore providing an origin site for the $\mathrm{Gb}_{3}$ receptor to be synthesized. Without this mutation causing partial synthesis of LPS, $\mathrm{Gb}_{3}$ receptors would lack a location to be synthesized. Additionally, when the $\lg t E$ and $\lg t C$ genes are introduced into mutant $E$. coli, $\mathrm{Gb}_{3}$ receptors are synthesized in place of LPS [1]. This allows E. coli to neutralize produced toxins.

Bacteriophages can exist in either a lytic cycle that kills the host bacteria, or a lysogenic cycle that incorporates the phage DNA into the bacterial chromosome [4]. Switching from the lysogenic to lytic cycle (prophage induction) occurs when a lambda repressor protein (C1) stops repressing lytic genes. When bacteria are stressed, RecA proteins are synthesized, which cleave $\mathrm{C} 1$ repressors, thereby allowing lytic genes to be expressed. By introducing the phage mutation $\lambda \mathrm{cl}$ ind-, cleavage by RecA proteins is greatly reduced, and the prophage is more likely to stay in the lysogenic cycle [5]. This mechanism can be harnessed to genetically modify bacteria without killing them.

We hypothesize that treating rats with a recombinant phage containing $E$. coli DNA encoding a $\mathrm{Gb}_{3}$ receptor will alleviate the pathogenic symptoms caused by Shiga toxinproducing $E$. coli and decrease $E$. coli poisoning recovery time.

\section{Methods \\ $\underline{\text { Subjects }}$}

Twenty-eight healthy, pathogen-free, male $(n=14)$ and female $(n=14)$ Wistar rats at 8 -weeks old (p56) will be used in this study [6,7] (Figure 1). Rats will be acclimatized to a light-dark cycle in which lights turn on at 8:00 and turn off at 20:00, and at a temperature of $21^{\circ} \mathrm{C}$. Rats will be kept at $90 \%$ of their free-feeding body weight, and all monitoring of symptoms will occur during their light cycle.

\section{Lab Procedure}

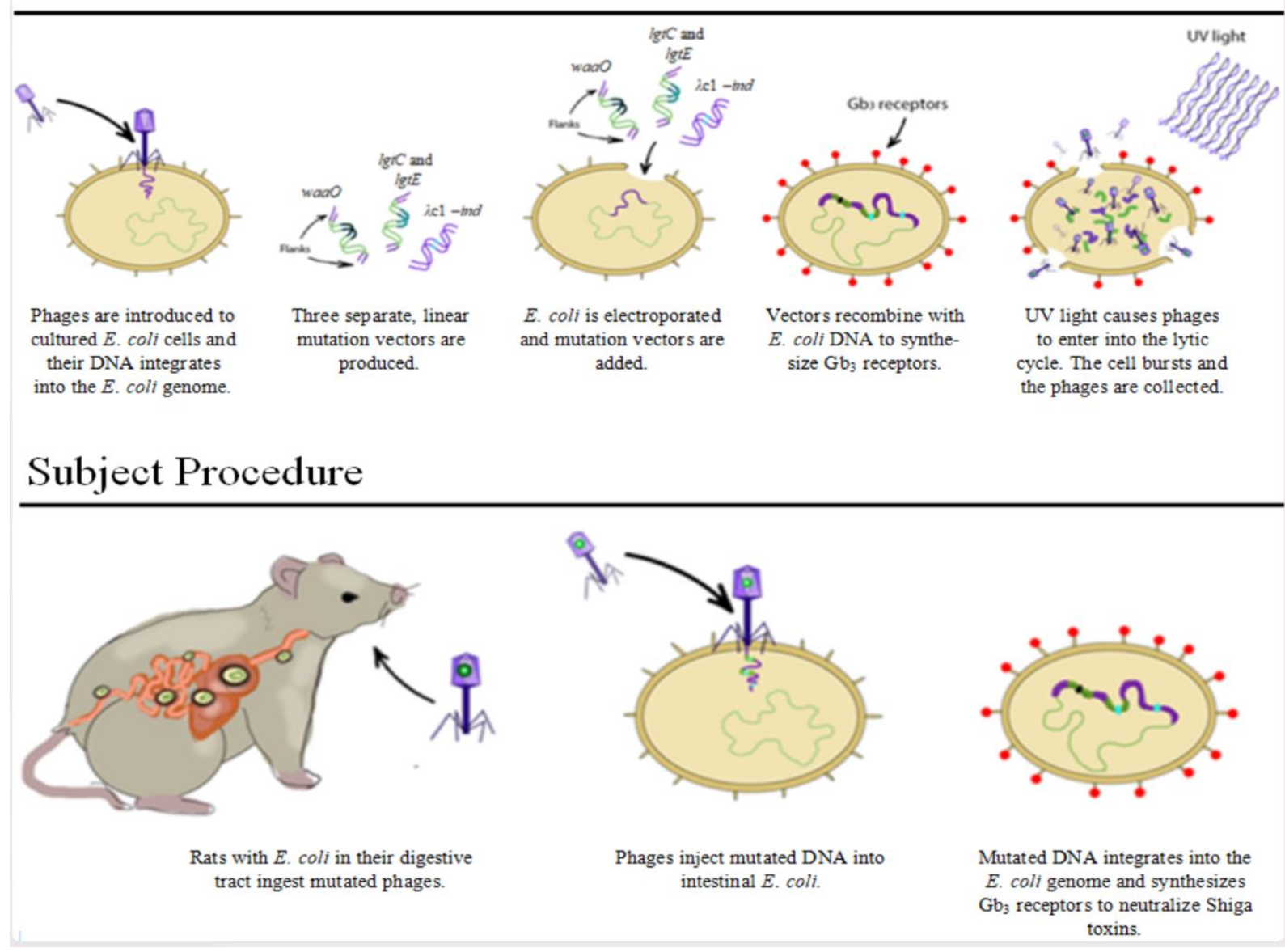

Figure 1. Mutant DNA recombineering process with $\lambda$ phage DNA in the lab, then in rat subjects. This figure was created using Adobe Photoshop. 
UNDERGRADUATE RESEARCH IN NATURAL AND CLINICAL SCIENCE AND TECHNOLOGY (URNCST) JOURNAL

Read more URNCST Journal articles and submit your own today at: https://www.urncst.com

Development of Mutation Vectors

To induce waaO mutations in $E$. coli, the waaO mutant DNA of waaO will first be synthesized by substituting an in-frame deletion [8]. Through asymmetric polymerase chain reaction (PCR), primers $\mathrm{A}, \mathrm{B}, \mathrm{C}$, and $\mathrm{D}$ will be used to create the deletion, then primers $\mathrm{A}$ and $\mathrm{D}$ will be used for amplification (Table 1). For the desired mutations to recombine with $\lambda$ phage DNA, the phage flanking sequences $\mathrm{J}$ and $\mathrm{K}$ (Table 1), will be added to the $5^{\prime}$ and $3^{\prime}$ ends of the waaO sequence, respectively, through recombination [9].

Table 1. Primers used for PCR and flanking [1,5,8]. The flanking sequences were chosen to incorporate mutations into regions of bacteriophage between coding regions and recombineering sites [16].

\begin{tabular}{|c|c|c|c|}
\hline & $\begin{array}{l}\text { Sequence } \\
\text { description }\end{array}$ & Function & Sequence \\
\hline A & $\begin{array}{l}\text { Upstream of waaO } \\
\text { gene }\end{array}$ & PCR primer & 5'-CGCGGATCCTCATTGCGGATGCCAGTAT-3' \\
\hline B & $\begin{array}{l}\text { Upstream of waaO } \\
\text { gene }\end{array}$ & PCR primer & 5'-CCCATCCACTAAACTTAAACAGCCATAAGCAACATGGAATG-3' \\
\hline $\mathrm{C}$ & $\begin{array}{l}\text { Downstream of } \\
\text { waaO gene }\end{array}$ & PCR primer & 5'-TGTTTAAGTTTAGTGGATGGGGCTCGTTATTGCGCTAAGCA-3' \\
\hline $\mathrm{D}$ & $\begin{array}{l}\text { Downstream of } \\
\text { waaO gene }\end{array}$ & PCR primer & 5'-CGCGGATCCCCCTCGTAAAAGCGTGAGTAA-3' \\
\hline $\mathrm{E}$ & $\begin{array}{l}\text { Upstream of } \lg t C / E \\
\text { gene }\end{array}$ & PCR primer & 5'-CAGACGGGATCCGACGTATCGGAAAAGGAGAAAC-3' \\
\hline $\mathrm{F}$ & $\begin{array}{l}\text { Upstream of } \lg t C / E \\
\text { gene }\end{array}$ & PCR primer & 5'-GCGCGCAATATATTCACCGCCACCCGACTTTGCC-3' \\
\hline G & $\begin{array}{l}\text { Downstream of } \\
\operatorname{lgt} C / E \text { gene }\end{array}$ & PCR primer & 5'-GGCAAAGTCGGGTGGCGGTGAATATATTGCGCGC-3' \\
\hline $\mathrm{H}$ & $\begin{array}{l}\text { Downstream of } \\
\operatorname{lgt} C / E \text { gene }\end{array}$ & PCR primer & 5'-CATGATGGATCCTGTTCGGTTTCAATAGC-3' \\
\hline I & $\begin{array}{l}\lambda \mathrm{cl} \text { ind-single base } \\
\text { pair mutated at } \\
\text { underlined } \mathrm{C} \text {. }\end{array}$ & $\begin{array}{l}\text { Mutation } \\
\text { sequence }\end{array}$ & $\begin{array}{l}\text { 5'-TGTTTTTTCTCATGTTCAGGCAGGGATGTTCTCACCCGAGCTTAG } \\
\text { AACCTTTACCAAAGGTGATGCGGAG-3' }\end{array}$ \\
\hline $\mathrm{J}$ & $\begin{array}{l}\text { Binding site } 1 \text { of } \lambda \\
\text { phage }\end{array}$ & Flanking & 5'-TGTTACAGGTCACTAATACCATCTAAG-3' \\
\hline K & $\begin{array}{l}\text { Binding site } 2 \text { of } \lambda \\
\text { phage }\end{array}$ & Flanking & 5'-TAGTTAGTTCATAGTGACATAT-3' \\
\hline $\mathrm{L}$ & $\begin{array}{l}\text { Binding site } 3 \text { of } \lambda \\
\text { phage }\end{array}$ & Flanking & 5'-TTCTCGTTCAGCTTTTTTATACTAAGTTGGCATT-3' \\
\hline M & $\begin{array}{l}\text { Sequence after } \\
\text { binding site } 3 \text { of } \lambda \\
\text { phage }\end{array}$ & Flanking & 5'-ATAAAAAAGCATTGCTTATCAATTTGTTGCAAC-3' \\
\hline
\end{tabular}


UNDERGRADUATE RESEARCH IN NATURAL AND CLINICAL SCIENCE AND TECHNOLOGY (URNCST) JOURNAL Read more URNCST Journal articles and submit your own today at: https://www.urncst.com

The second mutation will be induced by inserting $\lg t E$ and $\operatorname{lgt} C$ genes into the $E$. coli [1]. $\operatorname{lgt} E$ and $\lg t C$ will be mutated by overlap extension PCR using primers E, F, G, and $\mathrm{H}$, purified, then amplified using primers $\mathrm{E}$ and $\mathrm{H}$ (Table 1). Next, to allow for recombination with $\lambda$ phage, the phage flanking sequences $\mathrm{L}$ and $\mathrm{M}$ (Table 1 ) will be added to the 5' and 3' ends of the $\operatorname{lgt} E$ and $\operatorname{lgt} C$ sequence, respectively [9].

The third mutation, $\lambda \mathrm{c} 1$ ind-, will be synthesized through oligonucleotide synthesis by adding nucleotides in a cyclic 4 step process (blocking, coupling, capping, and oxidation) to a growing oligonucleotide chain, resulting in the sequence, I $[5,10]$ (Table 1). This sequence is complementary to the $\lambda \mathrm{cl}$ gene except for a single base pair mutation [5]. This DNA segment will then be amplified by PCR [8]. Since the $\lambda \mathrm{c} 1$ ind-gene contains entirely phage DNA, no flanking insertion elements will be needed.

The three mutations, waaO, $\operatorname{lgt} E$ and $\lg t C$, and $\lambda \mathrm{c} 1$ ind will be amplified by PCR. Then, in 2 separate solutions, $w a a O$ and $\operatorname{lgt} E / \operatorname{lgt} C$ will be digested with their respective flanking sequences by BamHI, treated with phosphate, then ligated to their respective flanking sequences to form 2 separate, linear vectors $[1,10]$. Since both the waaO and $\operatorname{lgt} E / \operatorname{lgt} C$ mutations and their respective flanking sequences contain restrictions sites for BamHI, it is important that we digest each mutation in separate solutions, to prevent the ligation of the 2 mutations to each other. This process is not required to create the $\lambda \mathrm{c} 1$ ind- mutation vector, as the addition of flanking sequences onto this mutation vector is not necessary. After the vectors are produced, they will then be transformed into $E$. coli cells via the recombineering process discussed below. Incorporation of manufactured mutation vectors into the $\lambda$ bacteriophage genome within the $E$. coli genome is possible due to either the presence of phage DNA within the vector (ie., $\lambda \mathrm{c} 1$ ind-mutation vector) or the addition of flanking sequences via digestion with BamHI (ie., $\operatorname{lgtE} / \operatorname{lgtC}$ and waaO mutation vectors).

\section{$\underline{\text { Recombineering Process }}$}

First, the E. coli cells will be infected with phages purchased from Sigma Aldrich to introduce the phage DNA into the bacterial cell [9]. After 125 minutes, the phage DNA should be fully incorporated into the bacterial chromosome as a prophage in the lysogenic cycle [11]. The waaO, lgtE and $\operatorname{lgt} C$, and $\lambda \mathrm{c} 1$ ind-vectors will be introduced into the cell through electroporation [9]. The prophage DNA then binds with the complementary flanks on the vectors, incorporating the mutations into its genome. Despite the $\lambda \mathrm{c} 1$ ind-mutation preventing the prophage from entering the lytic cycle, stress from UV light (315-400nm) can overcome this, causing the phages to replicate and lyse the cell [12]. The phages can then be collected and tested through immunofluorescence as described below through phage testing [9].
Phage Testing

To test the ability of the phages to modify $\mathrm{Gb}_{3}$ receptors in vitro before administering treatments in vivo, immunofluorescence will be used. There will be a control group (an $E$. coli cell culture that is not administered phage treatment) and phage treatment group of $E$. coli cell cultures that will both be treated first with primary antibodies specific to $\mathrm{Gb}_{3}$ receptors, then with secondary antibodies specific to the primary antibodies that also contain a fluorophore. After washing away excess antibodies, the amount of fluorescence corresponding to the quantity of $\mathrm{Gb}_{3}$ receptors present in the samples of $E$. coli cells can be quantified through spectroscopy. Both the control and treatment groups of $E$. coli cells will be tested to allow for comparison of the quantity of fluorescence between the groups. Adequate fluorescence quantified from the phage treatment group of $E$. coli cell cultures when compared to the control group will indicate that the $\mathrm{Gb}_{3}$ receptors are being expressed on the E. coli cells through phage treatment effectively.

\section{Treatment Protocol}

E. coli $(\mathrm{O} 157: \mathrm{H} 7$ strain) and $\lambda$ bacteriophages will be purchased from Sigma Aldrich chemical company to be used in this study. Rats will be separated into a control group ( $\mathrm{n}=4$ males and $\mathrm{n}=4$ females) (infected with $E$. coli) and a treatment group ( $n=10$ males and $n=10$ females) (infected with $E$. coli and given phage treatment). Phage treatments will consist of recombineered phages that were confirmed to contain the proper mutations necessary to cause expression of $\mathrm{Gb}_{3}$ receptors in the phage testing process. Both groups will be fed $0.1 \mathrm{~mL}\left(5 \times 10^{7} \mathrm{CFU}\right)$ samples of E. coli O157:H7 using a micropipette on day 0 $[6,14]$. The phage treatment will be administered to the treatment group orally in $0.1 \mathrm{~mL}$ samples on days $0-3$, twice per day, 2.5 hours apart to allow for full integration of treatment into the body before the next treatment is administered [6]. Control rats will be fed $0.1 \mathrm{~mL}$ of oral saline solution without phage treatment concurrently. To establish the effectiveness of phage therapy, stool samples collected daily will be analyzed for mutated $E$. coli using Lateral Flow Assay (LFA). LFA will be used to detect quantities of Shiga toxin in stool samples through the use of a pair of monoclonal antibodies. The LFA will produce a coloured line at the test line position that varies in saturation according to the presence and quantity of Shiga toxins within the stool samples. Symptoms such as bloody diarrhea, vomiting, and fever will also be monitored daily [15]. The experiment will continue for 10 days (Figures 2, $\underline{3}, \underline{4}$ ) [6]. Depending on susceptibility of the rats to $E$. coli, a possible limitation may arise if too many rats die before sufficient data is collected. 
UNDERGRADUATE RESEARCH IN NATURAL AND CLINICAL SCIENCE AND TECHNOLOGY (URNCST) JOURNAL

Read more URNCST Journal articles and submit your own today at: https://www.urncst.com

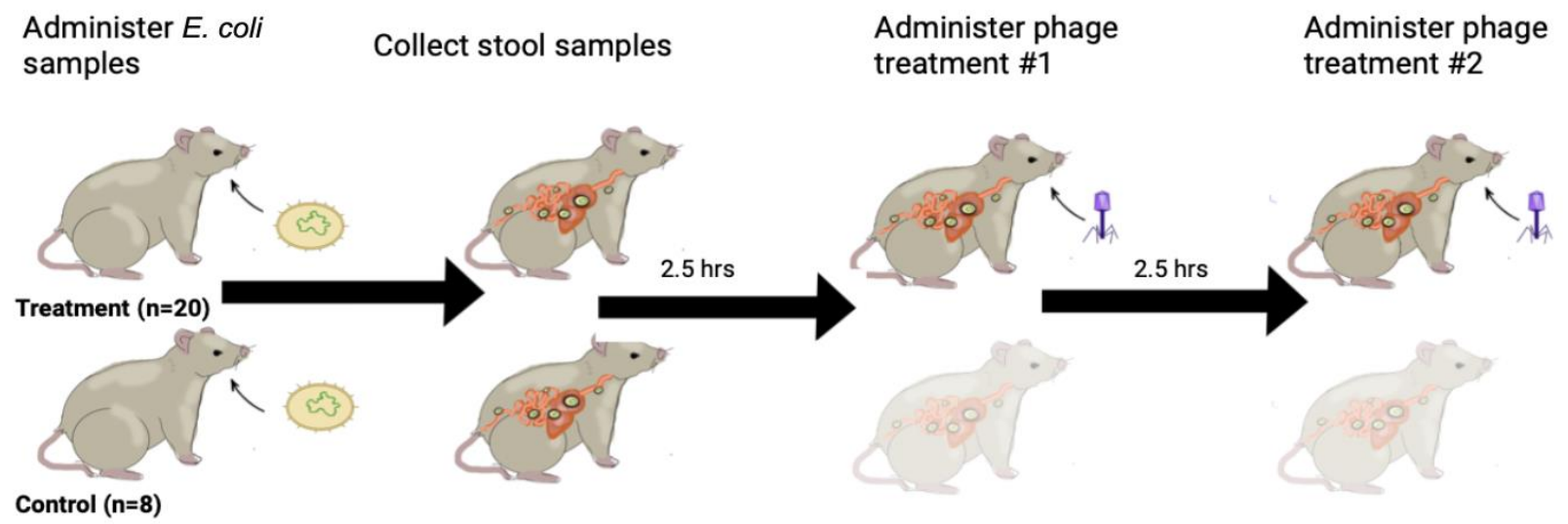

Figure 2. Day 0 treatment protocol: Administer E. coli to control and treatment groups, followed by stool sample collection from both groups, followed by two phage treatments to treatment group only [6]. This figure was created using Adobe Photoshop.

$\begin{array}{lll}\text { Collect stool samples } & \begin{array}{l}\text { Administer phage } \\ \text { treatment \#1 }\end{array} & \text { Administer phage } \\ & \text { treatment \#2 }\end{array}$

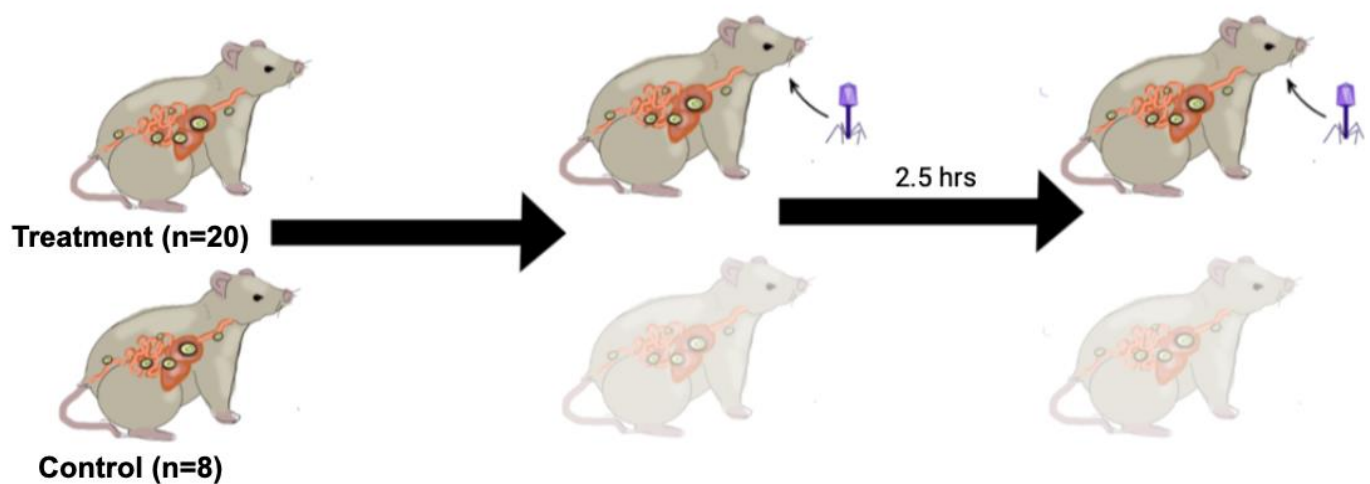

Figure 3. Days 1-3 treatment protocol: Stool sample collection from both groups followed by two phage treatments to treatment groups only [6]. This figure was created using Adobe Photoshop.

Day 5

Collect Stool samples

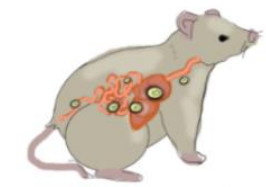

Treatment $(\mathbf{n}=\mathbf{2 0})$

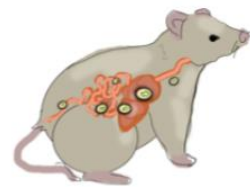

Control $(n=8)$
Day 10

Collect Stool samples
Day 10

Rats sacrificed

Figure 4. Days 5, 10 treatment protocol: Stool sample collection from both groups followed by sacrifice of the rats on day 10 [6]. This figure was created using Adobe Photoshop.

Karlovcec et al. | URNCST Journal (2021): Volume 5, Issue 11 
UNDERGRADUATE RESEARCH IN NATURAL AND CLINICAL SCIENCE AND TECHNOLOGY (URNCST) JOURNAL Read more URNCST Journal articles and submit your own today at: https://www.urncst.com

\section{Results}

As what we discussed here is proposed research, experimental results were not yet obtained, and the following discussion will be limited to expected results only.

We expect that the group of $E$. coli cells that received phage treatment prior to being administered to test subjects will fluoresce significantly when compared to the control group of cells, due to the insertion of $\mathrm{Gb}_{3}$ receptors via recombination. Secondly, we expect that the quantity of symptoms related to E. coli poisoning will be significant in the control group, increasing as the study proceeds. We expect that the quantity of symptoms in the treatment group will be much smaller when compared to the control group, and it may be possible that the treatment group presents no visible disease throughout the course of the study following phage treatment on day 0. Lastly, we anticipate that the amount of Shiga toxins present in the stool samples of the treatment and control groups will follow the same relationship as the symptoms of $E$. coli poisoning. Upon adequate expression of $\mathrm{Gb}_{3}$ receptors, we expect that the treatment group's stool samples will present smaller quantities of Shiga toxin when compared to the control group.

\section{Discussion}

The use of immunofluorescence allows for the confirmation of $\mathrm{Gb}_{3}$ receptor presence in a given sample. The introduction of primary antibodies specific to $\mathrm{Gb}_{3}$ receptors, followed by the introduction of fluorophoreconjugated secondary antibodies specific for the primary antibodies, allows for the visualization of $\mathrm{Gb}_{3}$ receptors. Therefore, if our phage treatment was successful in the treatment group of $E$. coli cells, we should see a significant amount of fluorescence in the treatment sample when compared to the control sample. Once antibodies have been administered, the fluorescence present in the treatment and control group samples will be visualized using a fluorescence microscope and quantified using a spectrofluorometer. The spectrofluorometer will measure and quantitatively collect the fluorescence produced by the fluorophores through absorbance readings. When analyzing the spectra produced by the spectrofluorometer, we expect a significant increase in absorbance at a wavelength that is associated with our selected fluorophore for the treatment sample, and minimal to no absorbance at that given wavelength for the control sample. This will indicate that our treatment was successful in causing the expression of $\mathrm{Gb}_{3}$ receptors in E. coli cells in the treatment group, and we will be able to proceed with the administration of $E$. coli cells and phage treatments to live subjects.

After administration of E. coli cells to both control and treatment groups and the introduction of phage treatment to the treatment group only, an unbiased observer who is unaware of the purpose of our research will monitor and quantify the symptomology of both the treatment and control groups of subjects daily. The observer will monitor both groups of rats and will record the frequency of any symptoms of $E$. coli poisoning that appear in the subjects. The observer will record frequencies of symptoms such as vomiting, diarrhea, and fatigue. Internal temperature of the rats will be attained daily to determine the presence of fevers, which will also be recorded. Once the study has been completed after 10 days, frequencies of symptoms for the treatment and control groups will be plotted on respective histograms to allow for comparison of symptomatology between the groups. We expect that as the study proceeds, the quantity of symptoms in the control group will increase and plateau. For the treatment group, as the study progresses, we expect quantities of symptoms to be lower compared to the control group, dependent upon adequate expression of $\mathrm{Gb}_{3}$ receptors, and therefore a decrease in Shiga toxin quantities. This will indicate that the phage treatment was successful in treating E. coli infection in the treatment group.

Stool samples will be collected daily from both the treatment and control group to be analyzed for quantities of Shiga toxin using LFA. We expect an increasing quantity of Shiga toxin in the control group as the study progresses. Therefore, we expect to see an increasing amount of saturation at the test line position of the LFA for the control group as the study progresses. For the treatment group, we expect to see a decrease in quantity of Shiga toxin upon adequate expression of $\mathrm{Gb}_{3}$ receptors on E. coli cells. As a result, for the treatment group, we expect to see a smaller amount of saturation at the test line position of the LFA when compared to the control group, upon adequate $\mathrm{Gb}_{3}$ receptor expression. This will indicate that the phage treatment was successful in causing expression of $\mathrm{Gb}_{3}$ receptors in the treatment group $E$. coli cells, and that the $\mathrm{Gb}_{3}$ receptors were successful in degrading the Shiga toxins produced by the E. coli cells in this group. With these results, we can conclude that our phage treatment methods may provide a possible alternative therapeutic capable of mitigating the effects of $E$. coli related diseases.

It is possible that the survival of rats in the phage treatment group may be attributed not to our proposed methods, but to phages with the $\lambda \mathrm{c} 1$ ind- mutation failing to maintain their lysogenic cycle, resulting in the lysing of $E$. coli cells. We may be able to tell if the $\lambda c 1$ ind-mutation is successful within the phages during the production of recombineered phages. This is because during production of the phages, we need to use UV light to allow the phages to overcome the $\lambda \mathrm{c} 1$ ind- mutation and lyse the cell. However, if we see that cells are being lysed before the addition of UV light, we would know that the mutation was unsuccessful at keeping the phage in its lysogenic cycle, and we would have to modify our methods before administering this phage treatment to the subjects. To further confirm that our phage treatment methods are successful and $E$. coli cells are not being lysed by our recombineered phages, we could conduct further testing 
UNDERGRADUATE RESEARCH IN NATURAL AND CLINICAL SCIENCE AND TECHNOLOGY (URNCST) JOURNAL Read more URNCST Journal articles and submit your own today at: https://www.urncst.com

using quantitative PCR (qPCR) assays to determine the quantities of $E$. coli cells in collected stool samples. If our methods are working as proposed, we would expect to see a consistent quantity of $E$. coli cells in the treatment group's stool samples throughout the experiment. However, if our phage treatments were in fact causing lysing of the $E$. coli cells, we would see a decrease in the quantity of $E$. coli cells in the treatment group's stool samples throughout the experiment and would again need to modify our methods.

\section{Conclusions}

Our proposed approach to mitigating the pathogenic effects of $E$. coli focuses on neutralizing Shiga toxins by recombining mutant DNA with $E$. coli through the use of phage infection, instead of killing the bacteria. By keeping mutated $E$. coli cells alive and allowing them to proliferate with $\mathrm{Gb}_{3}$ receptors that mitigate the pathogenic effects of the Shiga toxins, we will effectively create a population of $E$. coli cells in the organism that may not be harmful. These methods are important as they bypass the recurring issue of antibiotic resistance, as keeping the mutated $E$. coli cells alive prevents any resistant $E$. coli from having a selective advantage by having access to their resources. With these proposed methods, we offer a potential therapeutic for $E$. coli-related diseases and suggest an alternative method to prevent further acceleration of antibiotic resistance. If the results of this study are as expected, future directions for this research include beginning clinical trials in humans to test the efficacy of this phage treatment against $E$. coli poisoning. As well, future research may be conducted to further understand the bacteriophage-pathogen relationship underlying our methods and to determine if they may be used to mediate the effects of other pathogens on human health.

\author{
List of Abbreviations Used \\ $\mathrm{Gb}_{3}$ : globotriaosylceramide \\ LPS: lipopolysaccharides \\ $\mathrm{C} 1$ : lambda repressor protein \\ PCR: polymerase chain reaction \\ LFA: lateral flow assay \\ qPCR: quantitative polymerase chain reaction \\ UV: ultraviolet \\ E. coli: Escherichia coli
}

\section{Conflicts of Interest}

The authors declare that they have no conflicts of interest.

\section{Ethics Approval and/or Participant Consent}

This study did not require ethics approval or participant consent, as it is a proposal for research, and no humans, animals, or tissues were used.

\section{Author's Contributions}

JMK: made substantial contributions to the design of the study, drafted the manuscript, and gave final approval of the version to be published.

BDP: made substantial contributions to the design of the study, drafted the manuscript, and gave final approval of the version to be published.

ELV: made substantial contributions to the design of the study, drafted the manuscript, and gave final approval of the version to be published.

\section{Acknowledgements}

We would like to thank Anthony Nyguen for guiding us through the SCINAPSE Undergraduate Research Competition, which lead us to be able to submit our manuscript for publication, Elspeth Smith, and Jasmin Lalonde, for proofreading and offering edits on the first draft of our manuscript, and Jennifer Geddes-McAlister, Baozhong Meng, and Cezar Khursigara for proofreading and offering edits on our final draft of our manuscript.

\section{Funding}

This study was not funded.

\section{References}

[1] Paton A, Morona R, Paton J. Neutralization of Shiga toxins Stx1, Stx2c, and Stx2e by recombinant bacteria expressing mimics of globotriose and globotetraose. Infection and Immunity. 2001 Mar;69(3):1967-1970. https://doi.org/10.1128/IAI.69.3.1967-1970.2001

[2] CDC [Internet]. Antibiotic resistance threats in the United States. [cited 2020 Nov 21]. Available from: https://www.cdc.gov/drugresistance/biggest-threats.html

[3] Majowicz S, Scallan E, Jones-Bitton A, Sargeant J, Stapleton J, Angulo F, et al. Global incidence of human Shiga toxin-producing Escherichia coli infection and deaths: A systematic review and knowledge synthesis. Foodborne Pathogens and Disease. 2014 Jun;11(6):44755. https://doi.org/10.1089/fpd.2013.1704

[4] Atsumi S, Little J. Role of the lytic repressor in prophage induction of phage $\lambda$ as analyzed by a modulereplacement approach. Proceedings of the National Academy of Sciences of the United States of America. 2006 Mar;103(12):4558-4563. https://doi.org/10.1073/ pnas.0511117103

[5] Sauer R. DNA sequence of the bacteriophage $\lambda \mathrm{cl}$ gene. Nature. 1978 Nov;276:301-302. https://doi.org/ $\underline{10.1038 / 276301 \mathrm{a} 0}$

[6] Dissanayake U., Ukhanova M., Moye Z., Sulakvelidze A., Mai V. Bacteriophages reduce pathogenic Escherichia coli counts in mice without distorting gut microbiota. Frontiers in Microbiology. 2019 Sep; 1984(10):1-13. https://doi.org/10.3389/fmicb.2019.01984 
UNDERGRADUATE RESEARCH IN NATURAL AND CLINICAL SCIENCE AND TECHNOLOGY (URNCST) JOURNAL

Read more URNCST Journal articles and submit your own today at: https://www.urncst.com

[7] Furusawa T, Iwano H, Hiyashimizu Y, Matsubara K, Higuchi $\mathrm{H}$, Nagahata $\mathrm{H}$, et al. Phage therapy is effective in a mouse model of bacterial equine keratitis. Applied and Environmental Microbiology. 2016 Aug;82(17):5332-5339. https://doi.org/10.1128/AEM $.01166-16$

[8] Jimenez N, Senchenkova S, Knirel Y, Pieretti G, Corsaro M, Aquilini E, et al. Effects of lipopolysaccharide biosynthesis mutations on $\mathrm{K} 1$ polysaccharide association with the Escherichia coli cell surface. Journal of Bacteriology. 2012 Jul;194(13):3356-3367. https://doi.org/10.1128/JB.00329-12

[9] Marinelli L., Hatfull G., Piuri, M. Recombineering. Bacteriophage. 2012 Jan 1;2(1):5-14. https://doi.org/ 10.4161/bact. 18778

[10] Millipore Sigma [Internet]. DNA oligonucleotide synthesis. [cited 2020 Nov 19]. Available from: https://www.sigmaaldrich.com/technical-documents/ articles/biology/dna-oligonucleotide-synthesis.html

[11] Shao Q, Hawkins A, Zeng L. Phage DNA dynamics in cells with different fates. Biophysical Journal. 2015 Apr;108(8):2048-2060. https://doi.org/10.1016/j.bpj .2015 .03 .027
[12] Gupta A, Avci P, Dai T, Huang Y-Y, Hamblin M. Ultraviolet radiation in wound care: Sterilization and stimulation. Advances in Wound Care. 2013 Oct;2(8):422-437. https://doi.org/10.1089/wound.2012 .0366

[13] Mayo Clinic [Internet]. E. coli. [updated 2020 Oct 10; cited 2020 Nov 19]. Available from:

https://www.mayoclinic.org/diseases-conditions/e-coli/ diagnosis-treatment/drc-20372064

[14] Mushtaq N, Redpath M, Luzio J.P, Taylor P. Treatment of experimental Escherichia coli infection with recombinant bacteriophage-derived capsule depolymerase. Journal of Antimicrobial Chemotherapy. 2005 Apr;56(1):160-165. https://doi.org/10.1093/jac/ dki177

[15] Mayo Clinic [Internet]. E. coli. [updated 2020 Oct 10; cited 2020 Nov 19]. Available from:

https://www.mayoclinic.org/diseases-conditions/e-coli/ symptoms-causes/syc-20372058

[16] SnapGene [Internet]. Lambda plasmid. [cited 2020 Nov 19]. Available from: https://www.snapgene.com/ resources/plasmid-files/?set=basic_cloning_vectors \&plasmid=lambda

\author{
Article Information \\ Managing Editor: Jeremy Y. Ng \\ Peer Reviewers: Siobhan O’Brien, Kate Jiang \\ Article Dates: Received Jun 15 21; Accepted Aug 13 21; Published Nov 1121
}

\title{
Citation
}

Please cite this article as follows:

Karlovcec JM, Paget BD, Veres EL. The use of the $\lambda$ bacteriophage to neutralize the pathogenic effects of Shiga toxins from Escherichia coli to combat antimicrobial resistance: A research protocol. URNCST Journal. 2021 Nov 11: 5(11).

https://urncst.com/index.php/urncst/article/view/295

DOI Link: https://doi.org/10.26685/urncst.295

\section{Copyright}

(C) Jessica M. Karloveec, Brendan D. Paget, Emma L. Veres. (2021). Published first in the Undergraduate Research in Natural and Clinical Science and Technology (URNCST) Journal. This is an open access article distributed under the terms of the Creative Commons Attribution License (https://creativecommons.org/licenses/by/4.0/), which permits unrestricted use, distribution, and reproduction in any medium, provided the original work, first published in the Undergraduate Research in Natural and Clinical Science and Technology (URNCST) Journal, is properly cited. The complete bibliographic information, a link to the original publication on http://www.urncst.com, as well as this copyright and license information must be included. 
UNDERGRADUATE RESEARCH IN NATURAL AND CLINICAL SCIENCE AND TECHNOLOGY (URNCST) JOURNAL

Read more URNCST Journal articles and submit your own today at: https://www.urncst.com

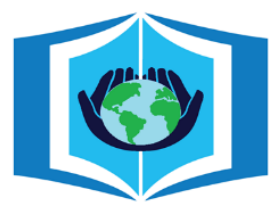

\section{URNCST Journal \\ "Research in Earnest"}

\section{Funded by the Government of Canada}

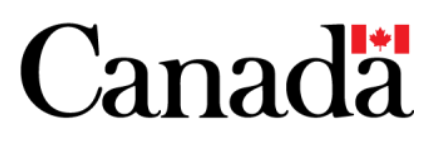

Do you research in earnest? Submit your next undergraduate research article to the URNCST Journal!

| Open Access | Peer-Reviewed | Rapid Turnaround Time | International | | Broad and Multidisciplinary | Indexed | Innovative | Social Media Promoted |

Pre-submission inquiries? Send us an email at info@ urncst.com | Facebook, Twitter and LinkedIn: @URNCST Submit YOUR manuscript today at https://www.urncst.com! 